\title{
PENGARUH METODE PENEMUAN TERBIMBING DAN KEMAMPUAN BERPIKIR KRITIS TERHADAP KEMAMPUAN MATEMATIKA SISWA KELAS IV SD SEKECAMATAN SETIABUDI JAKARTA SELATAN
}

\author{
Jumhariyani \\ Mahasiswa S2 Pendidikan Dasar Universitas Negeri Jakarta \\ Email : jumhariyani 88@yahoo.com
}

\begin{abstract}
ABSTRAC : This research goals to determined the effect of Instructional Media and Self Regulated Learning toward Mathematics ability. The research was conducted in $4^{\text {th }}$ grade state primary school Menteng Atas 11 Pagi Setiabudi South Jakarta in $2^{\text {nd }}$ semester 2015/2016 academic year. The data collected by test and analyzed by ANOVA. The research found: 1) Student's mathematics ability learned discovery learn methode is higher than student learned using ekspositori methode; 2) there is an interaction effects between learned using discovery methode and critical thinking ability learning toward mathematics ability; 3) for students who have higher critical thinking ability, their mathematics ability better if they learned using discovery learn methode; 4) for students who have lower criticl thinking, their mathematics ability better if they learned ekspositori methode.The results of this research indicate that discovery methode and critical thinking ability learning can improve mathematics ability.
\end{abstract}

Keywords: Learning Methode, Discovery Learning Methode, Ekspositori Methode, Critical Thinking Ability, Mathematics Abilitiy.

\begin{abstract}
ABSTRAK : Penelitian ini bertujuan untuk menganalisis pengaruh metode penemuan terbimbing dan kemampuan berpikir kritis terhadap kemampuan matematika. Penelitian ini dilakukan di SDN Menteng Atas 11 Jakarta Selatan pada kelas IV semester dua tahun pelajaran 2015/2016. Pengumpulan data dilakukan melalui tes dan dianalisis menggunakan ANOVA. Hasil penelitian menunjukkan bahwa: 1) kemampuan matematika siswa yang belajar menggunakan metode penemuan terbimbing lebih tinggi daripada kemampuan matematika siswa yang belajar menggunakan metode ekspositori; 2) terdapat pengaruh interaksi antara metode penemuan terbimbing dan kemampuan berpikir kritis terhadap kemampuan matematika; 3) bagi siswa yang memiliki kemampuan berpikir kritis tinggi, kemampuan matematika siswa tinggi jika siswa belajar menggunakan metode penemuan terbimbing; 4) bagi siswa yang memiliki kemampuan berpikir kritis rendah, kemampuan matematika siswa tinggi jika siswa belajar menggunakan metode ekspositori. Hasil penelitian ini menunjukkan bahwa metode penemuan terbimbing dan kemampuan berpikir kritis dapat meningkatkan kemampuan matematika.
\end{abstract}

Kata Kunci : Metode Pembelajaran, Metode Penemuan Terbimbing, Metode Ekspositori, Kemampuan Berpikir Kritis, Kemampuan Matematika. 
Pengaruh Metode Penemuan Terbimbing Dan Kemampuan Berpikir Kritis Terhadap Kemampuan Matematika Siswa

Jumhariyani

Matematika memegang peranan penting dalam pendidikan baik sebagai objek langsung seperti fakta, konsep, dan prinsip maupun sebagai objek tidak langsung seperti berpikir kritis, logis, tekun, mampu memecahkan masalah dan lain-lain. Oleh karena itu, matematika begitu penting untuk pengembangan ilmu-ilmu yang lain, maka pengajaran matematika telah dimulai dari tingkat Sekolah Dasar (SD) sampai Sekolah Menengah Atas (SMA).

Pada tahun 2007 dalam ajang IMO (International Mathematics Olympiads) (https://jsplife.wordpress. com/tag/pisa/) Indonesia hanya mam-pu menempati peringkat 52 dari 93 negara peserta. Berdasarkan hasil penelitian TIMSS (Trends Inter-national Mathematics and Science Study) yang diadakan setiap empat tahun sekali memperlihatkan bahwa peringkat Indonesia semakin lama semakin menurun. Pada penelitian TIMSS yang terakhir tahun 2011 Indonesia menempati peringkat 38 dari 42 negara peserta. Berdasarkan hasil penelitian dari beberapa lembaga dunia terkait pendidikan matematika menunjukkan bahwa nilai rata-rata matematika siswa
Indonesia diatas negara Suriah, Maroko, Oman, dan Ghana.

Dalam kegiatan pembelajaran matematika di sekolah-sekolah wila-yah Menteng Atas kualitas prestasi siswa kurang memuaskan. Hal ini disebabkan oleh banyaknya siswa yang kurang mampu menemukan konsep dan pengetahuan prosedural sehingga tidak mampu menerapkan matematika dalam pemecahan masalah. Selain itu, siswa kurang diberikan kesempatan untuk mengemukakan gagasan dan juga keputusan dalam proses pembelajaran. Pembelajaran dikelas yang di dominasi oleh guru dan belajar secara konvensional membuat siswa tidak aktif dan kemampuan matematika tidak berkembang dengan baik. Pembelajaran lebih fokus pada penyelesaian soal dan kurangnya pemahaman guru akan metode pembelajaran yang dapat meng-embangkan kemampuan berpikir kritis siswa. Guru mengajar cenderung pada pengetahuan prosedural untuk menyelesaikan soal membuat siswa harus menghafal prosedur tanpa mengetahui makna atau konsepnya terlebih dahulu. Proses belajar tersebut menghambat tumbuh kembangnya potensi kemam-puan berpikir, 
bernalar, berkomunikasi dan pemecahan masalah. Pengetahuan guru mengenai variasi metode pem-belajaran yang juga masih minim turut mendukung kemampuan berpikir kritis siswa menjadi kurang berkembang. Oleh karena masih rendahnya kemam-puan matematika siswa, maka perlu adanya metode pembelajaran yang dapat melatih kemampuan berpikir kritis siswa untuk meningkatkan kemampuan matematika siswa.

Metode pembelajaran penemuan adalah suatu metode pembelajaran dimana dalam proses belajar mengajar guru memperkenankan siswa-siswanya menemukan sendiri informasi-informasi yang secara tradisional bisa diberitahukan atau diceramahkan saja (Suryabrata, 1997: 1972). Metode pembelajaran ini merupakan suatu cara untuk menyampaikan ide/gagasan melalui proses menemukan. Fungsi pengajar disini bukan untuk menyelesaikan masalah bagi peserta didiknya, melainkan membuat peserta didik mampu menyelesaikan masalah itu sendiri (Hudojo, 1988, 114). Metode pembelajaran yang ekstrim seperti ini sangat sulit dilaksanakan karena peserta didik belum sebagai ilmuwan, tetapi mereka masih calon ilmuwan. Peserta didik masih memerlukan bantuan dari pengajar sedikit demi sedikit sebelum menjadi penemu yang murni. Jadi metode pembelajaran yang mungkin dilaksanakan adalah metode pembelajaran penemuan terbimbing. Dengan demikian kegiatan belajar mengajar melibatkan secara maksimum baik pengajar maupun pesertra didik.

Seperti uraian di atas bahwa penemuan terbimbing (Guided Discovery) merupakan salah satu dari jenis metode pembelajaran penemuan. Oleh Howe (dalam Hariyono, 2001: 3) menyatakan bahwa penemuan terbimbing tidak hanya sekedar keterampilan tangan karena pengalaman, kegiatan pembelajaran dengan model ini tidak sepenuhnya diserahkan pada siswa, namun guru masih tetap ambil bagian sebagai pembimbing. Penemuan terbimbing merupakan suatu metode pembelajaran yang tidak langsung (Indirect Instuction). Siswa tetap memiliki porsi besar dalam proses penyelenggaraan kegiatan pembelajaran.

Matematika berasal dari bahasa latin yaitu mathein atau mathenein yang berarti mempelajari. Matematika adalah pola berpikir, pola meng-organisasikan 
Pengaruh Metode Penemuan Terbimbing Dan Kemampuan Berpikir Kritis Terhadap Kemampuan Matematika Siswa Jumhariyani

pembuktian logis. Menurut James (Erman Suherman, 2000: 38) matematika adalah ilmu logika mengenai bentuk, susunan, besaran dan konsep-konsep yang berhubungan satu dengan yang lainnya dengan jumlah yang banyak yang terbagi dalam tiga bidang yaitu aljabar, analisis dan geometri. National Assessment of Educational Progres (NAEP) mengaitkan antara kemampuan dan matematika menjadi 3 tahapan yaitu (1) pemahaman kon-septual (conceptual understanding), (2) pengetahuan prosedural (proce-dural knowledge), dan pemecahan masalah (problem solving). Jihad (Asep Jihad, 2010:149) yang mengungkapkan pemahaman kon-septual merupakan kompetensi yang dimiliki siswa dalam memahami konsep dan dalam melakukan prosedur (algoritma) secara luwes, akurat, efisien, dan tepat. Pengetahuan prosedural menurut Van De Walle (John Van De Walle, 2009:29) adalah pengetahuan tentang aturan atau cara yang digunakan untuk menyelesaikan tugas-tugas matematika. Banyak cara atau langkahlangkah dalam me-nyelesaikan suatu soal dalam matematika. Pengetahuan prosedural dapat menjelaskan kepada siswa tentang aturan dalam menggunakan langkah untuk menyelesaikan suatu soal. Hudoyo menyatakan pemecahan masalah dalam matematika merupakan tipe belajar yang menyangkut 2 atau lebih aturan-aturan yang telah dimiliki siswa dimana aturan-aturan itu dikombinasikan agar menghasilkan suatu aturan yang tadinya belum diketahui siswa.

Menurut Eggen dan Kauchak dalam Jacobsen (Jacobsen,2009:222) penemuan terbimbing adalah suatu metode pembelajaran yang disusun untuk menjelaskan konsep-konsep dan hubungan antar konsep. Konsep atau prinsip yang ditulis dengan jelas akan menciptakan pembelajaran yang terarah dan sistematis. Hal ini mem-permudah guru dan siswa pada proses pembelajaran sehingga pembelajaran tersebut menjadi lebih bermakna. Beberapa tahapan dalam metode penemuan terbimbing yaitu pengenal-an/reevieew (orientasi siswa dalam masalah), tahap terbuka (mengorganisasikan siswa dalam masalah), tahap konvergen (menyajikan/ mempresentasikan), dan tahap penutup (mengevaluasi kegiatan dan hasil kegiatan).

Pada kelas kontrol digunakan metode ekspositori Imam musbikin (Imam Musbikin, 
2009:343) meng-ungkapkan bahwa informasi yang disampaikan guru berupa teori, generalisasi, hukum atau dalil beserta bukti yang mendukung. Guru telah mengolah bahan pengajaran sehingga siap disampaikan. Metode pem-belajaran ekspositori memiliki beberapa prinsip yang perlu diperhatikan oleh guru, antara lain beroriantasi pada tujuan, prinsip komunikasi, prinsip kesiapan dan prinsip keberlanjutan.

Scriven dalam Fisher (Alec Fisher, 2009:8-10) menambahkan, berpikir kritis adalah interprestasi dan evaluasi yang terampil dan aktif terhadap observasi dan komunikasi, informasi dan argumentasi. Interpretasi disini yakni mengkonstruksi dan menyeleksi yang paling baik dari beberapa alternative. Informasi merujuk pada lebih dari sekedar informasi melainkan mencakup pertanyaan, dan ungkapan. Argumen-tasi terdiri dari bahasa yang menyajikan berbagai alasan untuk membuat suatu kesimpulan. Berpikir kritis tidak hanya menganalisis dan melakukan evaluasi, melainkan mencakup pada interpretasi terhadap observasi, komunikasi dan argumen-tasi dengan terampil memenuhi standar-standar tertentu dengan melihat relevansi dan kejelasannya dan keterlibatan aktif siswa dengan kegiatan tanya-jawab serta dengan proses metakognisi.

\section{METODE}

Penelitian ini menggunakan pendekatan kuantitatif dengan metode eksperimen. Variabel penelitian terdiri dari satu variable terikat dan dua variable bebas sebagai berikut:

1. Variabel terikat (Y) adalah kemampuan matematika.

2. Variabel bebas pertama $\left(\mathrm{X}_{1}\right)$ adalah metode penemuan ter-bimbing dan metode ekspositori

3. Variabel bebas kedua $\left(\mathrm{X}_{2}\right)$ adalah berpikir kritis yang terbagi menjadi berpikir kritis tinggi dan berpikir kritis rendah.

Desain eksperimen meng-gunakan desain treatment by level 2 x 2. Sampel dalam penelitian ini diperoleh dari sebagian dari jumlah dan karakteristik populasi tersebut. Teknik pengambilan sampel dengan penelitian ini adalah cluster random sampling, yaitu pemilihan sampel dengan memilih secara random bukan individual tetapi kelompok-kelompok, dan semua 
Pengaruh Metode Penemuan Terbimbing Dan Kemampuan Berpikir Kritis Terhadap Kemampuan Matematika Siswa Jumhariyani

anggota (kelompok) mempunyai karakteristik yang sama.

Mengukur kemampuan mate-matika dikembangkan tes berupa essai yang mengacu pada KTSP Sekolah Dasar mata pelajaran matematika tahun 2006 yang terdiri dari 7 soal dan penilaian mengacu pada rubrik. Mengukur kemampuan berpikir kritis adalah skor yang diperoleh siswa setelah menjawab soal yang berbentuk essay untuk mengukur kemampuan berpikir kritis dan penialaian mengacu pada rubrik.

Uji hipotesis menggunakan analisis varians (ANOVA) dua jalan dan dilanjutkan dengan uji t-Dunnet untuk menentukan kelompok kemampuan matematika lebih tinggi secara sigifikansi dengan $\alpha=0,05$. Hipotesis alternative ditolak jika $\mathrm{t}$ hitung $>\mathrm{t}$ tabel. Hal ini berarti terdapat pengaruh yang positif signifikan perbedaan media interaktif dan alat peraga terhadap kemampuan matematika, namun jika $\mathrm{t}$ hitung $<\mathrm{t}$ tabel maka hipotesis alternatif diterima. Hal ini berarti tidak terdapat pengaruh yang positif antara perbedaan metode penemuan terbimbing dan ekspositori dan berpikir kritis terhadap kemampuan matematika.

\section{HASIL}

Analisis statistik deskriptif kemampuan matematika yang diperoleh dari perlakuan metode pembelajaran yaitu metode penemuan terbimbing dan ekspositori mengungkapkan bahwa rata-rata kemampuan matematika kelompok siswa yang diajar dengan menggunakan metode penemuan terbimbing. selanjutnya rangkuman deskripsi data kelompok siswa yang diajar menggunakan metode penemuan terbimbing (A1) dan metode ekspositori (A2). Diketahui bahwa rata-rata kemampuan matematika kelompok siswa yang memiliki kemampuan berpikir kritis tinggi sebesar 77,68 dan standar deviasi sebesar 10,6559. Rata-rata kemampuan matematika kelompok siswa yang memiliki kemampuan berpikir kritis rendah sebesar 72,21 dan standar deviasi 9,4452. (perhitungan pada lampiran 5 hal 180). Secara visual kecenderungan data kemampuan matematika kelompok siswa berpikir kritis tinggi,

Adapun skor pengaruh interaksi media pembelajaran dan kemandirian belajar menurut indikator kemampuan matematika . bahwa pada kelompok siswa yang memiliki kemampuan berpikir kritis tinggi dengan metode penemuan terbimbing pada indikator I memperoleh 96,87, indikator II 95,31, 
indikator III 96,09, indikator IV 92,96, matematika dari ke empat kelompok indikator $\mathrm{V}$ 82,81, indikator VI 78,12. mempunyai varians sama (homogen).

Sedangkan kelompok siswa yang memiliki kemampuan berpikir kritis tinggi dengan metode ekspositori pada indikator I memperoleh 83,59, indikator II 79,68, indikator III 76,56, indikator IV 59,37, indikator V 45,31, indikator VI 39,06.

Kriteria pengujian $\mathrm{H}_{o}$ diterima bila $\mathrm{L}_{\mathrm{o}}$ (Lhitung) $<$ dari harga L ( $\left.\mathrm{L}_{\text {tabel }}\right)$ berarti sampel berasal dari populasi yang berdistribusi normal. Hasil penghitungan uji normalitas dengan menggunakan uji Liliefors menunjukkan bahwa empat kelompok data berdistribusikan normal. Setelah Uji Normalitas salah satu syarat yang perlu dilakukan sebelum menguji hipotesis penelitian adalah Uji Homogenitas menggunakan perhitungan statistik pada taraf $\alpha=0,05$. Uji Homogenitas dilakukan untuk mengetahui apakah carian populasi bersifat homogen. Hipotesis yang akan diuji: $H_{0}: \sigma_{11}^{2}=\sigma_{12}{ }^{2}=\sigma_{21}^{2}=\sigma_{22}^{2}$ vs $H_{1}:$ Bukan $H_{0}$

Dari hasil analisis disajikan pada tabel diperoleh $\mathrm{F}=1,450 ; \mathrm{db} 1=3 ; \mathrm{db} 2=60$, dan p-value $=0,237>0,05$ atau $\mathrm{H}_{\mathrm{o}}$ diterima. Dengan demikian, data kemampuan

\section{PENELITIAN}

Temuan penelitian yang mengungkapkan bahwa kemampu-an matematika siswa yang diajarkan menggunakan metode penemuan terbimbing lebih tinggi daripada metode ekspositori menunjukkan bahwa metode penemuan ter-bimbing berpengaruh lebih efektif dibandingkan dengan metode ekspositori. Capaian rata-rata ke-mampuan matematika yang diajar dengan menggunakan metode penemuan terbimbing sebesar 75,64 dan rata-rata kemampuan mate-matika yang diajar dengan menggunakan metode ekspositori sebesar 72,53. Apabila capaian ini di-bandingkan dengan criteria ketuntasan ideal yaitu 75 maka kelompok siswa yang diajar dengan metode penemuan terbimbing sudah mencapai ketuntasan belajar individu sedangkan kelompok siswa yang menggunakan metode ekspositori belum mencapai ke-tuntasan ideal tersebut.

Menurut Eggen dan Kauchak dalam Jacobsen, penemuan terbimbing adalah suatu metode pembelajaran yang disusun untuk menjelaskan konsep-konsep dan hubungan 
Pengaruh Metode Penemuan Terbimbing Dan Kemampuan Berpikir Kritis Terhadap Kemampuan Matematika Siswa

Jumhariyani

antar konsep. Konsep atau prinsip yang ditulis dengan jelas akan menciptakan pembelajar-an yang terarah dan sistematis. Hal ini mempermudah guru dan siswa pada proses pembelajaran sehingga pembelajaran tersebut menjadi lebih bermakna. Berdasarkan hasil temuan penelitian terbukti bahwa kemampuan matematika siswa yang belajar menggunakan metode penemuan terbimbing lebih baik karena siswa diaktifkan dalam pembelajaran dengan langkah-langkah kegiatan yang menarik. Pembelajaran dengan penemuan terbimbing akan membangun konsep yang kuat karena ditemukan sendiri oleh siswa. Suasana pembelajaran pun lebih me-nyenangkan karena siswa berperan aktif dan guru hanya sebagai fasilitator.

Selanjutnya, Imam musbikin menambahkan bahwa informasi yang disampaikan guru berupa teori, generalisasi, hukum atau dalil beserta bukti yang mendukung. Guru telah mengolah bahan pengajaran sehingga siap disampai-kan. Metode pembelajaran ekspositori memiliki beberapa prinsip yang perlu diperhatikan oleh guru, antara lain beroriantasi pada tujuan, prinsip komunikasi, prinsip kesiapan dan prinsip keberlanjutan. Prinsip tersebut perlu diperhatikan oleh guru dalam menerapkan metode pembelajaran ekspositori ini. Berdasarkan hasil temuan penelitian terbukti bahwa ke-mampuan matematika siswa yang belajar menggunakan metode ekspositori kurang baik karena siswa kurang aktif dalam pembelajaran sehingga siswa tidak dapat menemukan konsep yang sedang dipelajari. Siswa sebagai subjek dari pembelajaran dimana siswa hanya menerima informasi dari guru. Pada pembelajaran ini guru berperan aktif.

Temuan diatas sesuai dengan penelitian yang dilakukan oleh Anna Fauziah (2010) yang dilakukan terhadap siswa kelas VIII SMP Negeri di Bandung menunjukkan bahwa peningkatan kemampuan pemahaman matematika siswa yang pembelajarannya melalui strategi Relating, Experiencing, Appliying, Cooperating and Transfereing (REACT) hasilnya lebih baik daripada peningkatan kemampuan pemahaman matematika siswa yang pembelajarannya secara konvensional. Peningkatan kemampuan pemecahan masalah matematika siswa yang pembelajarannya melalui strategi REACT lebih baik daripada peningkatan kemampuan pemecahan masalah matematika 
siswa yang pembelajarannya secara konvensional. Dengan demikian, terdapat keterkaitan yang signifikan antara kemampuan pemahaman dan pemecahan masalah di kelas eksperimen. Berdasarkan hasil temuan penelitian terbukti bahwa kemampuan matematika siswa yang belajar menggunakan metode penemuan terbimbing lebih tinggi karena siswa menemukan sendiri konsep yang dipelajari dengan adanya media belajar.

Berpikir kritis adalah proses terarah dan jelas yang digunakan dalam kegiatan mental seperti memecahkan masalah, mengambil keputusan, membujuk, menganalisis asumsi, dan melakukan penilitan ilmiah. Berpikir kritis adalah kemampuan untuk berpendapat dengan cara yang terorganisasi. Untuk mengembangkan kesadaran berpikir kritis siswa, guru dan siswa bersama-sama terlibat untuk memecahkan masalah agar terjadi dialog dan komunikasi horizontal. Pelaksanaan pendidikan dengan cara dialog akan membangkitkan kesadaran berpikir kritis siswa.

Selanjutnya temuan penelitian mengungkapkan bahwa rata-rata kemampuan matematika siswa yang belajar menggunakan metode penemuan terbimbing lebih tinggi daripada metode ekspositori pada siswa yang memiliki kemampua berpikir kritis tinggi. Sedangkan untuk siswa yang memiliki kemampuan berpikir kritis rendah ternyata kemampuan matematika yang belajar menggunakan metode penemuan terbimbing lebih rendah daripada siswa yang belajar menggunakan metode ekspositori. Hal ini berarti metode penemuan terbimbing lebih efektif berpengaruh pada kelompok siswa yang memiliki kemampuan berpikir kritis tinggi dibandingkan dengan kemampuan berpikir kritis rendah.

Temuan ini didukung dengan penelitian yang dilakukan oleh Tri Cahyaningsih lulusan UNJ 2013 dalam laporan penelitiannya berjudul Pengaruh Pembelajaran POE (Prediction-ObservationExplanation) terhadap Kemampuan Berpikir Kritis MATEMATIKA Siswa Kelas V (Studi Penelitian eksperimen Kelurahan Johar Baru Kecamatan Johar Baru Jakarta Pusat). Hasil penelitian tersebut menunjukkan bahwa pembelajaran POE berpengaruh signifikan tehadap kemampuan berpikir kritis MATEMATIKA siswa SD yakni dengan $t_{\text {hitung }}>t_{\text {tabel }}$ yaitu $3,39>2,06$. Peneliti 
Pengaruh Metode Penemuan Terbimbing Dan Kemampuan Berpikir Kritis Terhadap Kemampuan Matematika Siswa

Jumhariyani

mengambil penelitian yang dilakukan Tri Cahyaningsih karena dalam pembelajaran POE terdapat prediksi, observasi/ pengamatan dan eksplanasi/ penjelasan. Pada kegiatan-kegiatan tersebut kemampuan berpikir kritis dimulai dari mengumpulkan informasi, menganalisis, sampai pada mengevaluasi suatu pernyatan serta membuat kesimpulan dapat berkembang. Dengan adanya kegiatan pengamatan, kemampuan berpikir kritis siswa dapat mengumpulkan informasi dan menganalisis dapat berkembang serta siswa menjadi terampil dalam memilih informasi yang relevan. Kemampuan mengevaluasi dan memberikan kesimpulan juga dapat berkembang pada tahap eksplanasi yakni dengan pemberian kesempatan siswa dalam menjelaskan hasil temuannya. Hal ini menunjukkan bahwa terdapat perbedaan yang signifikan antara kemampuan matematika siswa yang memiliki kemampuan berpikir kritis tinggi dengan siswa yang memiliki kemampuan berpikir kritis rendah.

Temuan lain dari penelitian ini adalah adanya interaksi antara metode pembelajaran dan kemampuan berpikir kritis terhadap kemampuan matematika siswa. Hal ini mengandung arti bahwa metode pembelajaran bersama-sama dengan kemampuan berpikir kritis dapat meningkatkan kemampuan matematika. Selanjutnya interaksi antara metode pembelajaran dengan kemampuan berpikir kritis siswa akan memberikan pengaruh yang lebih efektif terhadap kemampuan matematika.

\section{SIMPULAN}

Berdasarkan hasil penelitian yang dilaksanakan di SDN Menteng Atas 11 Pagi Setiabudi Jakarta Selatan dengan menggunakan metode pembelajaran yaitu metode penemuan terbimbing dan metode ekspositori, maka dapat disimpulkan bahwa:

Kemampuan matematika siswa yang belajar menggunakan metode penemuan terbimbing lebih tinggi daripada kemampuan matematika siswa menggunakan metode ekspositori. Hal ini berarti metode penemuan terbimbing memberikan pengaruh lebih efektif terhadap kemampuan matematika dibandingkan metode ekspositori.

Terdapat pengaruh interaksi antara metode pembelajaran dan kemampuan berpikir kritis siswa terhadap kemampuan matematika. Hal ini berarti penggunaan 
metode penemuan terbimbing dan metode ekspositori mempunyai pengaruh yang efektif terhadap kemampuan matematika sangat bergantung pada tingkat kemampuan berpikir kritis siswa.

Kemampuan matematika yang diajar menggunakan metode penemuan terbimbing lebih tinggi daripada kemampuan matematika yang diajar menggunakan metode ekspositori untuk siswa yang memiliki kemampuan berpikir kritis tinggi. Hal ini berarti penggunaan metode penemuan terbimbing memberikan pengaruh yang lebih efektif terhadap kemampuan matematika, dengan mempertimbangkan karakteristik kemampuan berpikir kritis siswa dalam pembelajaran akan lebih baik dan efektif.

Kemampuan matematika yang diajar menggunakan metode penemuan terbimbing lebih rendah daripada kemampuan matematika yang diajar menggunakan metode ekspositori untuk siswa yang memiliki kemampuan berpikir kritis rendah. Hal ini berarti penggunaan metode ekspositori memberikan pengaruh yang lebih efektif terhadap kemampuan matematika pada siswa yang memiliki kemampuan berpikir kritis rendah.

\section{DAFTAR RUJUKAN}

Abdul Halim Fathani,2009. Matematika

Hakikat dan Logika Jogjakarta: Arruzz Media, 2009

Afgani, Jarnawi dan Eka Fitrajaya, 2006. Metode Pmebelajaran

Matematika Berbasis Keterampilan Berfikir dan Penalaran. Jurnal Peningkatan Mutu Pembelajaran Matematika dan Sains.,Bandung: Mimbar Pendidikan.

Alec Fisher,2008, Berpikir Kritis: Sebuah Pengantar terjemahan Benyamin Hadinata Jakarta: Erlangga

Antik. 2006. Metode Penemuan Terbimbing. (Online)

https://antik2006.wordpress.com/metode -penemuan-terbimbing/. Diakses pada tanggal 16 maret 2015

Asep Jihad.2008. Pengembangan Kurikulum Matematika (Bandung: multi pressindo.

Asmawi Zainul dan Noehi,1997 Penilaian Hasil Belajar .Jakarta: Dirjen Dikti UT.

Dani, Irfan.2013. Metode Pembelajaran Penemuan Terbimbing. (Online) 
Pengaruh Metode Penemuan Terbimbing Dan Kemampuan Berpikir Kritis Terhadap

Kemampuan Matematika Siswa

Jumhariyani

http://pustaka.pandani.web.id/2013/

$\underline{12 / \text { metode-pembelajaran-penemuan- }}$

terbimbing.html. Diakses pada

tanggal 16 maret 2015

David A. Jacobsen, Paul Eggen dan Donald Kauchak,2009. Methods for Teaching: Metode-etode pengajaran meningkatkan belajar siswa TK-SMA terjemahan Fawaid dan Khoirul Anam. Yogyakarta: Pustaka Belajar.

Dede Suratman,2010. Pemahaman Konseptual dan Pengetahuan Prosedural Materi Pertidaksamaan Linear Satu Variabel Siswa Kelas VII $S M P$, Jurnal Pontianak: Universitas Tanjungpura.

Dennis K. Filsaime, Menguak Rahasia Berpikir Kritis dan Kreatif. Jakarta: PT. Prestasi Pustakarya.

Djamarah, S. 2005. Psikologi Belajar. Jakarta: Rineka Cipta.

Ella Yulaelawati, 2004. Kurikulum dan Pembelajaran: Filosofi, Teori dan Aplikasi Bandung: Pakar Raya.

Hake. 2003. Normalisasi Gain. (PDF Online). Bandung: Perpustakaan UPI Hamalik, O. 2008 Kurikulum dan Pembelajaran. Jakarta :PT Bumi Aksara
Kenneth D. Moore, 2005. Evective Instructional Strategies From Theory Practice America: sage Publications, Inc Mas'ud, A. 2010. Strategi Belajar Mengajar Dan Inovasi Pembelajaran. Lep Khair Slameto. 2003. Belajar dan Faktor-Faktor yang Mempengaruhinya (Edisi Revisi). Jakarta: Rineka Cipta Windiwati. 2013. Pembelajaran Matematika dengan Metode Penemuan Terbimbing. (Online) https://Windiwati.wordpress.com/pembe lajaran-matematika-dengan-modelpenemuan-terbimbing/. Diakses pada tanggal 16 maret 2015 